\title{
Differences in Demographic Characteristics of Potential Acquirers of Real Estate Rights: Cases from Slovenia and Japan
}

\author{
Bojan Grum \\ European Law Faculty in Nova Gorica Delpinova, Nova Gorica, Slovenia \\ Email: bgrum@siol.net
}

Received 28 April 2014; revised 12 May 2014; accepted 3 June 2014

Copyright (C) 2014 by author and Scientific Research Publishing Inc.

This work is licensed under the Creative Commons Attribution International License (CC BY).

http://creativecommons.org/licenses/by/4.0/

(c) (i) Open Access

\begin{abstract}
The aim of the study was to explore the role of demographic characteristics of potential acquirers of real estate rights. We were interested in whether the participants according to different origins of cultures and the basic demographic characteristics reflect a statistically significant difference. Results show that the participants who enter the Japanese real estate market are mainly male participants, who are single and have no children, and show a tendency to live in the city centre. Participants of both sexes enter the Slovene property market equally. On average they are married, childless and with a tendency to live at the outskirts of the city or inside agglomeration. Slovene participants expressed significantly higher satisfaction with the current residential status, which we relate to the findings that apartment owners compared to tenants express higher satisfaction with their living environment and are socially more active in their living environment.
\end{abstract}

\section{Keywords}

Real Estates, Demographic Characteristics, Comparison of Cultures, Slovenia, Japan

\section{Introduction}

Expectations of potential real estate buyers regarding the acquisition of real estate rights are diverse and differernt according to the demographic characteristics, buyers' needs, their wishes and interests, lawful options and material ability in modern economic environments. By observing the participants on the market many researchers attribute general recognition to certain factors on the market (Cohen et al., 2005; Temeljotov \& Zupančič, 2006; Thomas, 2008). Wong and Hui (2006) combine these factors into the factors of personal expectations and factors of external expectations. They link personal expectations to potential acquirers of real estate rights, in- 
vestors and owners who expect high (low) returns in the future when market grows (falls). They also have too high (too low) expectations regarding the rise (fall) in prices when expecting the future rise (fall) of prices on the market. They link participants' external expectations to the change of market prices and regulatory measures of the country. They note that particularly in times of expected rise in prices the country encourages investments and ownership through regulatory measures, whereas banks provide favourable loans. Factors of external expectations thus mainly include factors describing housing and tax legislation, regulatory measures and economic situation on the real estate market.

This paper explores the role of demographic characteristics of potential acquirers of real estate rights. We are interested in cross-cultural comparison of two different cultures, Slovenia as part of the European Union and Japan as a highly developed Asian country. We are interested in whether the participants according to different origins of cultures and the basic demographic characteristics (age, number of children in household, monthly means used for solving the housing problem), reflect a statistically significant difference.

Several sources suggest that the demographic characteristics of the population affect demand (and hence supply) in the housing market, the purchasing power of potential buyers of real estate and natural, living and socio-economic factors of real estate. By following the Commission's report on aging in the European Community (Aging Report, 2009), we found out that the population in Slovenia will rise only until 2019, when Slovenia is expected to have 2.1 million people or 2.4 per cent more than in 2007. The year 2019 is expected to experience a gradual decline in population, at least until 2060. The study predicts the minimal growth in the labour force by 2011, less than one per cent, whereas until 2060 the labour force is expected to fall by as much as one-third. The report predicts change in the aging population, so that the life expectancy, which is currently 65 years of age for both sexes, would extend for more than five years until 2060.

In Japan in 1995, the population aged 65 years and over represented 14 per cent of the population. Given the current trend in the rate of aging after the age of 65 years it will rise to as much as 27.4 per cent in 2025 and 32 per cent in 2050 (Makino, 2009). On the other hand, fertility is falling. As stated by Makino (2009), the Japanese society is changing - the old population is growing faster than in any other country. Convergence curves of movement of population and number of households in Japan show that Japan's average household size is decreasing (RREEF, 2009). As stated by Ministry of Land, Infrastructure, Transport and Tourism (MLIT, 2009) in the annual report of Land White Paper 2009, the population shows a negative trend and as a result after 2015, a number of household members are expected to fall. This means a long-term decline in demand for building land. The report (MLIT, 2009) also states that changes in the household, such as reduction of floor area, increasing number of old people, and the need for high technology (internet, communication) lead to greater demand for housing in cities. Pšunder (2009) notes that besides the increasing number of elderly people we must also consider the fall in the number of children as well as the fall in the working population. In his study he concludes on the assumption that GDP growth and demographic changes in key factors influence the price of real estate in which we lived, fewer people will need for your home less real estate and that are potentially able to allocate more money for them. A positive correlation between the annual gross domestic product per capita and the average number of property transactions is also confirmed by the real estate market research activities in Slovenia in the period 2000-2006 conducted by the (Drobne et al., 2009). In his research Bradeško (2003) confirmed key findings, trends and relationships from a study of the European Central Bank, highlighting the correlation of growth in real estate prices and real GDP growth and household income. Pšunder (2009) notes that the change in the movement GDP does not affect directly and a priori in property prices, but that the rise of GDP is one of the key influential factors influencing real estate prices.

The housing policy is therefore also related to the accessibility of apartments (such as a sufficient number of apartments on the market to meet demand, matching supply and demand, apartments affordability as well as suitability of housing costs) (Cirman, 2007). The affordability of apartments as measured by the internationally established level, according to which housing costs should not exceed the level of $30 \%$ household's disposable income, which in both observed countries is different. As stated by Cirman (2007), affordability of apartments is not questionable only when encumbering the income with housing costs but also when acquiring apartments or in terms of apartment affordability in view of financing a privately owned apartment. In this context, households face highly insufficient offer of non-profit sector, expensive market apartments and high prices of privately owned apartments.

\section{Hypothesis}

In the analysis we follow the hypothesis defining that the differences between potential acquirers of residential 
real estate according to the different origins of cultures and the basic demographic characteristics (age, number of children in household, monthly means for solving the housing problem) are statistically significant.

\section{Observed Demographic Factors}

For defining age groups we took into consideration the research conducted by Mandič (1995), where the participants' age group was defined on the basis of unified data processing of housing needs. This research shows that those seeking their dwelling are for the most part younger than middle-aged; up to 60 per cent of them were aged 25 to 34 years, whereas the seeker's average age was 32 years. The research also showed that the education level of those seeking housing is somewhat above the Slovene average. In Japan, Deutsch and his colleagues (2005) established that the average age of a Japanese person entering their own household is close to 40, which is high in comparison to America (29 years) or Austria (31 years). They say this is the result of bank politics determining the maximum burden of own income to 25 per cent and the minimum personal participation when purchasing real estate to 20 per cent of its value and of the high real estate prices. Based on the stated above we observe two age groups, the first from 20 to 29 years and the second from 30 to 40 years.

According to family status we distinguish single and married participants. Thomas (2008) notes that couples where both people are employed have better financial situation and enter real estate market more easily. The same difference is also mentioned by the Development and Research Project Housing Survey (Mandič, 2006), stating that by comparing different types of households, the best housing conditions have especially couples without children and the worst are found in one-parent households. In addition to this we are interested in how the demographic trends are linked to the expectations of potential real estate buyers. In Japan the total number of inhabitants has already reached its highest point but the number of households in Tokyo is still increasing. It is expected that the number of households in Tokyo is going to increase for at least a couple of years despite the falling trend of births. In a 40-year interval between 1980 and 2020, on the national level the number of households without children is expected to grow from 32 to 54 per cent (RREEF, 2009). Also according to the 2002 census data in Slovenia, two-person households (23.0 per cent) prevail, followed by single-person households (21.9 per cent) (SURS, 2009). For Japan it is estimated that the number of single households will increase, which means that compared to 1980 until 2030 the number of these households will double (RREEF, 2009).

We are interested in the monthly income used for resolving the housing problem. Apartment owners have on average the least problems and their income is on average the least burdened by housing costs (Mandič, 2006). It has been however established that the limit of 30 per cent monthly income used for resolving housing problem in Slovenia exceeds as much as 67 per cent of households in non-profit rental sector, 39 per cent in corporate and staff apartments and 54 per cent in privately rented apartments (Cirman, 2007). In addition to this, Cirman (2007) points out that the politics of subsidized rents can intervenes only in the sector of non-profit rents, but not in staff and market sector, which is why the continuation of a high proportion is expected also in the future. In Slovenia the total number of average housing costs exceeded the 30 per cent of household's available income already back in 2005 with 30.8 per cent, in 2006 with 31.3 per cent and in 2007 with 31.8 per cent (SURS, 2010). In Japan the total number of average housing costs ranges from 17.6 per cent in 2001 to almost 18 per cent in 2008 (Official Statistics of Japan, 2010). Relatively low affordability of privately owned apartments is therefore typical for the Slovene housing policy, which means that Slovene policy is relatively unsuccessful in ensuring apartments for affordable prices (Cirman, 2007). Problems can be attributed to the unresolved issue of denationalisation, difficult real estate sales to foreigners, problems with entries and their updates into the land register data, which in turn also affects the lending policy of the country (Temeljotov \& Zupančič, 2006).

\section{Methodology and Instruments}

In composing the questionnaire we considered the guidelines according to Tarik (1990) and took the questionnaire composed of three sets as the main instrument for measuring participants' expectations. We used the method of review based on the questionnaire (Walonic, 2007). The questionnaire was composed in the context of a broader research (Grum, 2010) for the survey being conducted in Slovenia and Japan and is aimed at determining the factors which have a decisive influence on potential acquirers of real estate rights when deciding to purchase real estate.

In analysing demographic characteristics we used the first set of the questionnaire which we subdivided beforehand. The first set of the questionnaire measures demographic factors and includes 34 variables. We defined 8 factors, which explain over $60 \%$ of the total variation (Bastič, 2006). The Kaiser-Meyer-Olkin measure of 
sampling adequacy is 0.7 . The Bartlett's test $(\mathrm{BT}=2178.1)$, which is statistically significant, shows that defined factors can be interpreted (Fulgosi, 1984). The reliability of the questionnaire established by the inner consistency method or the Cronbach's alpha coefficient indicates that the questionnaire expresses a high level of reliability. The Cronbach's alpha coefficient for the first set of the questionnaire is 0.8 .

The survey was conducted in two cultural environments, in Slovenia and Japan. The sample includes participants aged 20 to 40 who were selected according to cultural identity, gender, age, education, marital or family status and economic social status. 1270 participants took part in the survey.

Table 1 shows that there is only a solid $20 \%$ of Japanese participants of the total number of participants. This is the result of obtaining answers from Japanese participants, since in Japan the distribution of questionnaires in public places is restricted (without the authorisation of a special ethics committee). In contrast to Slovene participants, Japanese participants showed a great distrust to participating in on-line surveys. In terms of education, most participants have a higher education (49.5\%) which is followed by secondary education (30.6\%). In terms of the number of children in a joint household, most of participants do not have children (54.0\%). The majority of participants live at the city outskirts (36.2\%) or in the city centre (34.3\%).

Table 2 shows that the majority of participants owns or co-owns the apartment they live in (48.3\%), followed by participants living with their relatives (25.9\%). The majority of participants live in a house $(57.8 \%)$ or a block of flats (40.8\%). The majority of participants are employed (59.6\%). Of all participants, $84.5 \%$ of them spend approximately $30 \%$ of their monthly costs or less for resolving their current housing problem. In terms of satisfaction, most participants are satisfied with their current residence status (29.9\%).

\section{Results and Discussion}

We statistically analysed the results by conducting multivariate analysis of variance regarding the participants' different cultural identity and basic demographic (age, number of children in a joint household, average monthly means used for solving the housing problem) characteristics of participants. Table 3 showsthe results of multivariate analysis of variance regarding the affiliation to culture and participants' age.

According to Table 3 statistically significant differences regarding the affiliation to culture and the participants' age are shown in terms of gender, family status, location of apartment and expressed satisfaction with the current apartment.

Among Slovene participants there are more female participants in both age groups, which is even more distinctly expressed in the age group of 20 to 29 years old women (average rate is 1.280), whereas among Japanese participants there are more men in both age groups (average rate is 1.630 and 1.670). We can explain this by findings made by Hirayama (2008) who states that in the real estate area in Japan men predominate (as holders of family responsibility) and that women who enter especially to ownership area can be notable only in the last period. In this regard, he points out single women are still mostly excluded from ownership structures (Hirayama, 2008). This can also explain the indicated correlation between gender and ownership among Japanese participants (-0.137), which is shown in our research. Among Slovene participants, on the real estate market we do not detect any significant differences in terms of gender. That is why the participation of respondents is as anticipated equivalent to the ratio as shown by the census for the year 2009 of Statistical Office of the RS (SURS, 2009).

Among Slovene participants the most numerous are those who are in a relationship or married, whereas among Japanese participants those who are single, which is especially evident in the age group from 20 to 29 years, where among Japanese participants there are practically no participants involved in a relationship (average accordance rate is 1.00). With regard to family status, among Slovene participants those who are in a relationship or married particularly prevail, and with regard to number of children, those who do not have any children. This shows that the majority of participants are in a relationship but do not have children. Also according to the 2002 census data, two-person households (23.0 per cent) prevail, followed by single-person households (21.9 per cent) (SURS, 2009).

Most participants live in the centre or at the outskirts of a city. We associate this with the fact that the concentration of housing fund is the biggest in cities, which is especially typical of Japan. The research results show that Japanese participants in both age groups significantly show trends for living in the centre or at the outskirts of a city (average accordance rate in age group between 30 and 40 years is 1.50). In Slovenia the major cities comprise 40 per cent of all apartments together, however by taking into consideration also the percentage of 
Table 1. Structure of participants according to cultural identity, gender, age, education, family status, number of children in a joint household, place of residence.

\begin{tabular}{|c|c|c|c|c|c|c|}
\hline & \multicolumn{2}{|c|}{ Slovene participants } & \multicolumn{2}{|c|}{ Japanese participants } & \multicolumn{2}{|c|}{ Participants together } \\
\hline & number & percentage & number & percentage & number & percentage \\
\hline \multicolumn{7}{|l|}{ Cultural identity } \\
\hline Participants & 1006 & 79.2 & 264 & 20.8 & 1270 & 100.0 \\
\hline \multicolumn{7}{|l|}{ Gender } \\
\hline women & 623 & 49.0 & 90 & 7.0 & 713 & 56.1 \\
\hline men & 383 & 30.1 & 174 & 13.7 & 557 & 43.9 \\
\hline Total & 1006 & 79.2 & 264 & 20.8 & 1270 & 100.0 \\
\hline \multicolumn{7}{|l|}{ Age } \\
\hline aged 20 to 29 & 490 & 38.6 & 114 & 8.9 & 604 & 47.6 \\
\hline aged 30 to 40 & 516 & 40.6 & 150 & 11.8 & 666 & 52.4 \\
\hline Total & 1006 & 79.2 & 264 & 20.8 & 1270 & 100.0 \\
\hline \multicolumn{7}{|l|}{ Education } \\
\hline less than secondary school & 10 & 0.8 & 0 & 0.0 & 10 & 0.8 \\
\hline secondary school & 370 & 29.1 & 18 & 1.4 & 388 & 30.6 \\
\hline higher education & 533 & 41.9 & 96 & 7.5 & 629 & 49.5 \\
\hline masters degree or more & 93 & 7.3 & 150 & 11.7 & 243 & 19.1 \\
\hline Total & 1006 & 79.2 & 264 & 20.8 & 1270 & 100.0 \\
\hline \multicolumn{7}{|l|}{ Family status } \\
\hline single & 264 & 21.0 & 168 & 13.4 & 432 & 34.5 \\
\hline marital or non-marital partnership & 731 & 58.3 & 90 & 7.1 & 821 & 65.5 \\
\hline Total & 995 & 79.4 & 258 & 20.5 & 1253 & 100.0 \\
\hline \multicolumn{7}{|l|}{ Number of children in household } \\
\hline no children & 486 & 38.7 & 198 & 15.8 & 684 & 54.6 \\
\hline one child & 174 & 13.9 & 12 & 0.9 & 186 & 14.9 \\
\hline two children & 251 & 20.0 & 18 & 1.4 & 269 & 21.5 \\
\hline three children & 68 & 5.4 & 30 & 2.3 & 98 & 7.8 \\
\hline four or more children & 15 & 1.2 & 0 & 0.0 & 15 & 1.2 \\
\hline Total & 994 & 79.3 & 258 & 20.6 & 1252 & 100.0 \\
\hline \multicolumn{7}{|l|}{ Where you live (location) } \\
\hline in the city centre & 316 & 25.2 & 114 & 9.0 & 430 & 34.3 \\
\hline on the city outskirts & 321 & 25.6 & 132 & 10.5 & 453 & 36.2 \\
\hline densely populated rural settlement & 234 & 18.7 & 6 & 0.4 & 240 & 19.2 \\
\hline dispersed rural settlement & 116 & 9.3 & 0 & 0.0 & 116 & 9.3 \\
\hline elsewhere & 8 & 0.6 & 6 & 0.4 & 14 & 1.1 \\
\hline Total & 995 & 79.4 & 258 & 20.5 & 1253 & 100.0 \\
\hline
\end{tabular}

apartments and houses in other major cities, the total number is 65.3 per cent. Nevertheless, it is typical for Slovene participants, as stated by Hočevar and others (2004), that given the type of settlement more than half of respondents would prefer to live in a smaller or larger village (countryside), while only about 5 per cent of the respondents would move to the urban environment. This explains us the correlation we observed in our research between the current place of residence and the expected place of residence (0.183).

Within terms of expressed satisfaction with the current apartment, an interesting fact is that Slovene participants express higher satisfaction with their housing status and factors related to residential property, even though 
Table 2. Structure of participants in terms of apartment ownership, type of apartment, occupation, monthly costs for resolving housing problem, satisfaction with the current residence status.

\begin{tabular}{|c|c|c|c|c|c|c|}
\hline & \multicolumn{2}{|c|}{ Slovene participants } & \multicolumn{2}{|c|}{ Japanese participants } & \multicolumn{2}{|c|}{ Participants together } \\
\hline & number & percentage & number & percentage & number & percentage \\
\hline \multicolumn{7}{|l|}{ Ownership of the apartment: } \\
\hline owned or co-owned & 531 & 42.5 & 72 & 5.7 & 603 & 48.3 \\
\hline market rent & 99 & 7.9 & 96 & 7.6 & 195 & 15.6 \\
\hline non-profit & 27 & 2.1 & 24 & 1.9 & 51 & 4.1 \\
\hline with relatives & 269 & 21.5 & 54 & 4.3 & 323 & 25.9 \\
\hline other & 64 & 5.1 & 12 & 0.9 & 76 & 6.1 \\
\hline Total & 990 & 79.3 & 258 & 20.6 & 1248 & 100.0 \\
\hline \multicolumn{7}{|l|}{ Type of the apartment: } \\
\hline block of flats & 366 & 29.2 & 144 & 11.5 & 510 & 40.8 \\
\hline house & 608 & 48.6 & 114 & 9.1 & 722 & 57.8 \\
\hline other & 17 & 1.4 & 0 & 0.0 & 17 & 1.4 \\
\hline Total & 961 & 76.9 & 258 & 23.0 & 1249 & 100.0 \\
\hline \multicolumn{7}{|l|}{ Employment: } \\
\hline unemployed & 30 & 2.4 & 6 & 0.4 & 36 & 2.9 \\
\hline student & 304 & 24.3 & 126 & 10.0 & 430 & 34.4 \\
\hline employed & 630 & 50.4 & 114 & 9.1 & 744 & 59.6 \\
\hline other & 27 & 2.1 & 12 & 0.9 & 39 & 3.1 \\
\hline Total & 991 & 79.3 & 258 & 20.6 & 1249 & 100.0 \\
\hline \multicolumn{7}{|l|}{ Monthly expenses for resolving housing problem: } \\
\hline nothing & 450 & 36.2 & 60 & 4.8 & 510 & 41.1 \\
\hline less than $30 \%$ of personal monthly income & 216 & 17.4 & 150 & 12.0 & 366 & 29.5 \\
\hline approx. $30 \%$ of personal monthly income & 149 & 11.9 & 24 & 1.9 & 173 & 13.9 \\
\hline more than $30 \%$ of personal monthly income & 129 & 10.3 & 24 & 1.9 & 153 & 12.3 \\
\hline almost total personal income & 40 & 3.2 & 0 & 0.0 & 40 & 3.2 \\
\hline Total & 984 & 79.2 & 258 & 20.7 & 1242 & 100.0 \\
\hline \multicolumn{7}{|l|}{ Satisfaction with the current residence status: } \\
\hline very dissatisfied & 76 & 6.0 & 30 & 2.4 & 106 & 8.5 \\
\hline dissatisfied & 105 & 8.4 & 24 & 1.9 & 129 & 10.4 \\
\hline medium satisfied & 220 & 17.7 & 48 & 3.8 & 268 & 21.6 \\
\hline satisfied & 281 & 22.6 & 90 & 7.2 & 371 & 29.9 \\
\hline very satisfied & 300 & 24.1 & 66 & 5.3 & 366 & 29.5 \\
\hline Total & 982 & 79.1 & 258 & 20.8 & 1240 & 100.0 \\
\hline
\end{tabular}

the survey Research and Development Project-Housing Survey (Mandič, 2006) taking into account several pointers, estimates that 28 per cent of households have inadequate housing conditions. The research also shows that the average surface area according to the housing survey is $32.98 \mathrm{~m}^{2}$ per person, which is 1.19 of a room per person, and that 39 per cent of households in Slovenia has less than one room per person, which is in Europe considered as the housing statistics overpopulation. The research also showed other significant factors, such as excessive operating costs, poor or decrepit installation, poor infrastructure (Mandič, 2006). We explain the difference between the expressed satisfaction level among Slovene and Japanese participants by findings of the researches conducted by (Rohe \& Stegman, 1994; Rohe \& Stewart, 1996; Rohe \& Basolo, 1997; Rohe et al., 2001). (Rohe et al., 2001) studied social advantages of apartment owners and established that apartment owners 
Table 3. Structure of the results of multivariate analysis of variance regarding the affiliation to culture and participants' age.

\begin{tabular}{|c|c|c|c|c|c|c|c|c|c|c|}
\hline \multirow[t]{3}{*}{ Variable } & & \multirow{3}{*}{$\begin{array}{l}\text { Sum of } \\
\text { Squares }\end{array}$} & & \multirow{3}{*}{$\begin{array}{l}\text { Mean } \\
\text { Square }\end{array}$} & \multirow[t]{3}{*}{$\mathrm{F}$} & \multirow[t]{3}{*}{$\mathrm{p}$} & \multicolumn{4}{|c|}{ Average degree of agreement } \\
\hline & & & & & & & \multicolumn{2}{|c|}{ Slovene } & \multicolumn{2}{|c|}{ Japan } \\
\hline & & & & & & & 20 - 29 age & 30 - 40 age & 20 - 29 age & 30 - 40 age \\
\hline Gender & $*$ & 1.071 & 1 & 1.071 & 4.710 & 0.030 & 1.280 & 1.460 & 1.630 & 1.670 \\
\hline Age & & 0.339 & 1 & 0.339 & 1.031 & 0.310 & & & & \\
\hline Family status & $* * *$ & 7.350 & 1 & 7.350 & 42.966 & 0.000 & 1.610 & 1.850 & 1.000 & 1.620 \\
\hline No. of children & & 0.534 & 1 & 0.534 & 0.544 & 0.461 & & & & \\
\hline Location & $*$ & 5.045 & 1 & 5.045 & 5.326 & 0.021 & 2.190 & 2.160 & 1.840 & 1.500 \\
\hline Ownership & & 0.124 & 1 & 0.124 & 0.069 & 0.793 & & & & \\
\hline Type of apartment & & 0.747 & 1 & 0.747 & 2.894 & 0.089 & & & & \\
\hline Employment & & 0.702 & 1 & 0.702 & 2.835 & 0.093 & & & & \\
\hline Monthly expenses & & 3.093 & 1 & 3.093 & 2.362 & 0.125 & & & & \\
\hline Satisfaction & $* *$ & 17.382 & 1 & 17.382 & 11.327 & 0.001 & 3.740 & 3.740 & 3.520 & 3.380 \\
\hline
\end{tabular}

Note: * difference is statistically significant $(p<0.05)$;** difference is statistically significant $(p<0.01)$; *** difference is statistically significant $(p$ $<0.001)$.

compared to tenants express higher satisfaction with their living environment, they are socially more active in their living environment, relocate less often and contribute more to social stability of the neighbourhood. The research also showed that 86 per cent of American respondents believe that in terms of social security it is better to own an apartment than to rent one. 74 per cent of respondents think people should purchase an apartment as soon as they can afford it, whereas among respondents who rent an apartment 64 per cent answered they only rent an apartment because they can not afford one (Rohe et al., 2001). They estimate that the satisfaction level among apartment owners is higher (Rohe \& Stewart, 1996). In the example of Baltimore they observed apartment purchasers and tenants and after a year and a half found that the apartment purchasers showed higher satisfaction than the apartment tenants (Rohe \& Stegman, 1994). In a further three-year study Rohe and Basalo (1997) determined that even after a three-year ownership the apartment owners were still more self-satisfied than the tenants. They defined the self-satisfaction as the combination of common satisfaction with life, apartment and neighbourhood (Rohe \& Stewart, 1996). From this we can assume that a high percentage of owner-occupied apartments positively affects the participants' expressed satisfaction (apartment ownership rate in Slovenia is $80 \%$ and in Japan it is $60 \%$ ). Table 4 showsthe results of multivariate analysis of variance regarding the cultural identity/affiliation to culture and number of children in a joint household.

According to Table 4 statistically significant differences regarding the affiliation to culture and the number of children in terms of gender, age, family status, place of residence, type of apartment and satisfaction with the current apartment.

As far as the age of participants, in general it applies that by having more children in a joint household the participants' age is higher. However, the comparison shows that by comparing the number of children in a joint household the Japanese participants' age is essentially higher than those of Slovene participants. The comparison also shows that Japanese participants' level of education increases with higher number of children whereas among Slovene participants three or more children mean participants' lower level of education (average accordance level of Slovene participants is 2.73 , that of Japanese participants' is 4.00 ). This may show a sociably weaker structure of compared Slovene participants. The research also shows that the more educated participants are, the higher is the possibility to purchase an apartment using their own means. Trček (2005) also establishes that the factor most closely related to investing into real estate is the monthly household income. He notes that this factor mainly depends on the participants' education and the size of household (Trček, 2005). Our research also shows the correlation between education and the number of members in a joint household (0.117). What is interesting is also the comparison of the participants' place of residence regarding the number of children in a joint household. The comparison shows that among Slovene participants having more family members means living further away from the city centre, whereas among Japanese participants it is quite the opposite. For all participants also applies that by having more members in a joint household, the bigger is tendency for replacing 
an apartment with a house. This can be explained by the findings, which show among Slovene participants that considering the type of settlement more than half of people surveyed would prefer to live in a smaller or bigger village or rural environment, whereas only about 5 per cent of people surveyed would live in a bigger or big city (Hočevar et el., 2004). In the analysis of existing and desired housing units Pšunder and Ferlan (2009) established that in the future most of households (72.12 per cent) would like to live in a family house. The analysis also showed that 24.3 per cent of all respondents who currently live in city centres, other neighbourhood communities and in the countryside wish to relocate to the city outskirts.

Regarding the number of children in a joint household, in general, Slovene participants who have more family members in their household prevail. This is confirmed by statistic data. According to the findings of the Japanese National Institute of Population and Social Security Research, the average number of members per household in year 1995 was 2.82 and the expected number in year a mere 2.49, of which 30 per cent are single-person households (IPSS, 1998). According to SURS (2009), in Slovenia the average number of members per household in the same period was 3.0, of which 21.9 per cent were single-households. Table 5 shows the results of multivariate analysis of variance regarding affiliation to culture and monthly used costs for resolving the housing problem.

According to Table 5 statistically significant differences regarding the affiliation to culture and monthly use of means for solving the housing problem are shown in terms of gender, education, family status, number of children, ownership, type of apartment and satisfaction with the current apartment.

The results indicate that among Slovene participants who spend monthly about 30 per cent of income for resolving their housing problem the age structure is on average 30 years (average accordance rate is 2.61), while among Japanese participants it is about 35 years(average accordan cerate is 3.0). The results show that the monthly consumption of around 30 per cent is typical for Japanese participants who are in a relationship (average accordance rate is 2.00). The characteristic of Japanese participants who spend monthly more than 30 per cent is also that they live in an apartment (average accordance rate is 1.00), while of Slovene participants that they predominantly live in a house(average accordance rate is 1.57). We can explain this by the expressed higher level in terms of living with relatives, which can be as observed related to the fact that young people nowadays enter the ownership apartment fund much later than before (Deutsch et al., 2005). This has also been established by Ishikawa (2005), who states for Japan that in 2003 among apartment owners the age group from 20 to 29 represents 12 per cent, whereas in the age group from 30 to 40 years the percentage of ownership rises to $48 \%$. Tomoko (2010) states that young Japanese couples tend to live with their parents in a joint household on average approximately 10 years. Deutsch with his colleagues (2005) explicitly explains that in Japan in year 1989, there were actually 30 per cent of owner-occupied houses acquired by inheritance or succession and the percentage is still rising.

Table 4. Structure of the results of multivariate analysis of variance regarding the cultural identity/affiliation to culture and number of children in a joint household.

\begin{tabular}{|c|c|c|c|c|c|c|c|c|c|c|c|c|c|c|}
\hline \multirow[t]{3}{*}{ Var. } & & \multirow{3}{*}{$\begin{array}{l}\text { Sum of } \\
\text { Squares }\end{array}$} & \multirow[t]{3}{*}{ df } & \multirow{3}{*}{$\begin{array}{c}\text { Mean } \\
\text { Square }\end{array}$} & \multirow[t]{3}{*}{$\mathrm{F}$} & \multirow[t]{3}{*}{ Sig. } & \multicolumn{8}{|c|}{ Average degree of agreement } \\
\hline & & & & & & & \multicolumn{4}{|c|}{ Slovene } & \multicolumn{4}{|c|}{ Japan } \\
\hline & & & & & & & e1 & e2 & e3 & e4 & e1 & e2 & e3 & e4 \\
\hline a & $* *$ & 2.830 & 3 & 0.943 & 4.106 & 0.007 & 1.340 & 1.430 & 1.380 & 1.490 & 1.640 & 2.000 & 1.330 & 1.800 \\
\hline $\mathrm{b}$ & $* *$ & 2.655 & 3 & 0.885 & 4.378 & 0.004 & 2.290 & 2.720 & 2.770 & 2.620 & 2.450 & 2.500 & 3.000 & 3.000 \\
\hline c & $* *$ & 5.801 & 3 & 1.934 & 4.875 & 0.002 & 2.620 & 2.820 & 2.820 & 2.730 & 3.450 & 3.500 & 3.330 & 4.000 \\
\hline d & $* * *$ & 10.482 & 3 & 3.494 & 20.062 & 0.000 & 1.640 & 1.800 & 1.850 & 1.860 & 1.180 & 1.500 & 2.000 & 2.000 \\
\hline f & $* *$ & 15.545 & 3 & 5.182 & 5.535 & 0.001 & 2.070 & 2.170 & 2.280 & 2.460 & 1.730 & 1.500 & 1.670 & 1.200 \\
\hline g & & 10.513 & 3 & 3.504 & 1.764 & 0.152 & & & & & & & & \\
\hline $\mathrm{h}$ & $* * *$ & 5.328 & 3 & 1.776 & 7.229 & 0.000 & 1.610 & 1.590 & 1.710 & 1.830 & 1.360 & 1.000 & 1.670 & 2.000 \\
\hline $\mathrm{i}$ & & 0.945 & 3 & 0.315 & 0.952 & 0.414 & & & & & & & & \\
\hline $\mathrm{j}$ & & 5.295 & 3 & 1.765 & 1.333 & 0.262 & & & & & & & & \\
\hline $\mathrm{k}$ & $*$ & 16.413 & 3 & 5.471 & 3.622 & 0.013 & 3.500 & 3.560 & 3.860 & 3.940 & 3.450 & 3.500 & 3.000 & 4400 \\
\hline
\end{tabular}

Note: * difference is statistically significant $(p<0.05)$; ${ }^{* *}$ difference is statistically significant $(p<0.01)$; $* * *$ difference is statistically significant ( $p<0.001$ ). Legend: (a) gender, (b) age, (c) education, (d) family status, (f) place of residence, (g) ownership, (h) type of apartment, (i) employment, (j) monthly used means for solving the housing problem, (k) satisfaction; (e1) no children, (e2) one child, (e3) two children), (e4) three children. 
Table 5. Structure of the results of multivariate analysis of variance regarding affiliation to culture and monthly used costs for resolving the housing problem.

\begin{tabular}{|c|c|c|c|c|c|c|c|c|c|c|c|c|c|c|}
\hline \multirow[t]{3}{*}{ Var. } & & \multirow{3}{*}{$\begin{array}{l}\text { Sum of } \\
\text { Squares }\end{array}$} & \multirow[t]{3}{*}{$\mathrm{df}$} & \multirow{3}{*}{$\begin{array}{c}\text { Mean } \\
\text { Square }\end{array}$} & \multirow[t]{3}{*}{$\mathrm{F}$} & \multirow[t]{3}{*}{ Sig. } & \multicolumn{8}{|c|}{ Average degree of agreement } \\
\hline & & & & & & & \multicolumn{4}{|c|}{ Slovene } & \multicolumn{4}{|c|}{ Japan } \\
\hline & & & & & & & $\mathrm{j} 1$ & $\mathrm{~J} 2$ & j3 & j4 & $\mathrm{j} 1$ & $\mathrm{~J} 2$ & j3 & j4 \\
\hline $\mathrm{a}$ & & 1.649 & 3 & 0.550 & 2.368 & 0.069 & & & & & & & & \\
\hline $\mathrm{b}$ & $* * *$ & 6.043 & 3 & 2.014 & 8.683 & 0.000 & 2.420 & 2.620 & 2.610 & 2.600 & 2.200 & 2.640 & 3.000 & 2.500 \\
\hline c & $*$ & 3.581 & 3 & 1.194 & 2.997 & 0.030 & 2.620 & 2.860 & 2.780 & 2.810 & 3.500 & 3.480 & 3.750 & 3.500 \\
\hline $\mathrm{d}$ & $* * *$ & 8.554 & 3 & 2.851 & 15.022 & 0.000 & 1.690 & 1.730 & 1.850 & 1.770 & 1.100 & 1.360 & 2.000 & 1.250 \\
\hline $\mathrm{e}$ & $* * *$ & 53.529 & 3 & 17.843 & 16.663 & 0.000 & 1.900 & 1.910 & 2.130 & 1.960 & 1.000 & 1.600 & 3.000 & 1.000 \\
\hline $\mathrm{f}$ & & 6.385 & 3 & 2.128 & 2.257 & 0.080 & & & & & & & & \\
\hline g & $* *$ & 25.411 & 3 & 8.470 & 4.270 & 0.005 & 2.470 & 2.120 & 2.010 & 1.970 & 2.700 & 2.520 & 1.250 & 1.750 \\
\hline $\mathrm{h}$ & $* * *$ & 12.580 & 3 & 4.193 & 17.238 & 0.000 & 1.690 & 1.690 & 1.620 & 1.570 & 1.800 & 1.320 & 1.750 & 1.000 \\
\hline $\mathrm{i}$ & & 0.383 & 3 & 0.128 & 0.387 & 0.762 & & & & & & & & \\
\hline $\mathrm{k}$ & $* * *$ & 43.658 & 3 & 14.553 & 9.995 & 0.000 & 3.940 & 3.480 & 3.420 & 3.260 & 3.600 & 3.280 & 4.250 & 3.530 \\
\hline
\end{tabular}

Note: * difference is statistically significant $(p<0.05)$; ** difference is statistically significant $(p<0.01)$; *** difference is statistically significant ( $p<0.001)$. Legend: (a) gender, (b) age, (c) education, (d) family status, (e) number of children, (f) place of residence, (g) ownership, (h) type of apartment, (i) employment, (k) satisfaction; (j1) no, (j2) less than 30\%, (j3) around 30\%, (j4) more than $30 \%$.

\section{Conclusions}

In this article we explore the role of demographic characteristics of potential acquirers of residential real property rights. We are interested in cross-cultural comparison of two different cultures, Slovenia as part of the European Union and Japan as a highly developed Asian country. We are interested if there are in accordance to affiliation to different cultures and to the basic demographic characteristics (age, number of children in a joint household, monthly means used for solving the housing problem) statistically significant differences. As the main tool we used, a questionnaire was compiled as part of wider research being carried out in Slovenia and Japan. Its fundamental objective is to identify factors that are crucial for potential acquirers of real estate rights in deciding on the purchase of real estate. With the questionnaire we obtained credible information which we have statistically analyzed and by analysis of the results we confirmed the basic hypothesis stating that the observed basic demographic differences between participants regarding affiliation to different cultures are statistically significant.

The results show that Slovenian participants in both age groups (20 to 29 years and 30 to 40 years) dominate female participants; Japanese participants in both age groups dominate male participants (as holders of family responsibility) and that the entry of women, particularly in the ownership area is visible only in the last period. Among Slovene participants, the most numerous are the participants in a relationship with no children, while among Japanese participants, single participants stand out. Research shows that Slovene participants have more members in a household, which is also confirmed by the comparison of statistic data in both countries. In Japan, the average number of members per house hold in 2009 was 2.49, 30 per cent of which were single-person households, while in Slovenia in the same period the average number was 3.0 members per household, 21.9 per cent of which were single-person households. The results indicate that Japanese participants in both age groups clearly show trends for living in the centre or at the outskirts of the city, while the Slovene participants in both age groups show a tendency to live at the outskirts of the city or inside agglomeration. Considering the expressed satisfaction with the current residential status there is an interesting fact that Slovene participants in both age groups express higher satisfaction, which can be related to the findings that apartment owners compared to apartment tenants express higher satisfaction with their living environment; are socially more active in their living environment; relocate less often and contribute more to social stability of the neighbourhood. From this we can assume that a high percentage of owner-occupied apartments has a positive impact on the participants' expressed satisfaction (the rate of apartment ownership in Slovenia is $80 \%$ and in Japan it is $60 \%$ ). The results of the research indicate that the age structure of participants who monthly spend about 30 per cent of income for resolving the housing problem among Slovene participants is on average 30 years, while among Japanese par- 
ticipants it is about 35 years.

The research confirms that the affordability of apartments, as measured by internationally recognized limit, at which housing costs should not exceed limits of 30-per cent of disposable household income, in both compared countries is different. Compared to the Japanese housing policy, the Slovene housing policy is characterised as having relatively poor affordability of privately owned apartments. A high percentage of ownership is attributed mainly to the fact that in Slovenia, most people were solving their housing problems some time ago and mostly in the years when conditions were much more favourable.

\section{References}

Aging Report 2009 (2009). Economic and budgetary projections in the EU-27, Member States (2008-2060). Brussels: European Commission 2009.

Bastič, M. (2006). Metode raziskovanja. Maribor: Univerza v Mariboru, Ekonomsko poslovna fakulteta Maribor.

Bradeško, J. (2003). Trg nepremičnin in Centralna banka. In A. Kožar (Ed.), Poslovanje z nepremičninami. 14. Tradicionalno strokovno srečanje (pp. 16-25). Gospodarska zbornica Slovenije: Zbornik referatov.

Cohen, D. H., Kozak, R. A., Vidal, N., Spetic, W., \& Ide, R. (2005). Performance Expectations and Needs of the Japanese House Consumer. Forest Products Journal, 55, 37-44.

Cirman, A. (2007). Strategija rabe stanovanja mora biti usklajena s strategijo gospodarskega razvoja: Stanovanjska raba. In Posvet na temo: Različni nameni rabe stanovanj. Ljubljana: Državni svet RS.

http://www.ds-rs.si/kb/posveti/?View=entry\&EntryID=61

Deutsch, E., Tiwari, P., \& Moriizumi, Y. (2005). The Slowdown in the Timing of Housing Purchases in Japan in the 1990s. Journal of Housing Economics, 15, 230-256. http://dx.doi.org/10.1016/j.jhe.2006.09.007

Drobne, S., Grilj, T., \& Lisec, A. (2009). Dejavnost trga nepremičnin v Sloveniji v obdobju 2000-2006. Geodetski vestnik, 53, 543-560.

Fulgosi, A. (1984). Faktorska analiza. Zagreb: Filozofski fakultet v Zagrebu.

Grum, B. (2010). Primerjava pričakovanj potencialnih kupcev nepremičnin glede pridobitve nepremičninskih pravic $v$ različnih kulturnih obdobjih: Primer Slovenije in Japonske, Ph.D. Theses, Nova Gorica: Evropska pravna fakulteta.

Hirayama, Y. (2008). Women's Marital Status and Housing Tenure in the Context of Japan’s Home-Owning Society. Journal of Architecture and Planning, 73, 1045-1052. http://dx.doi.org/10.3130/aija.73.1045

Hočevar, M., Kos, D., Makarovič, J., Trček, F., Štebe, J., \& Uršič, M. (2004). Vrednote prostora in okolja. CRP, Konkurenčnost Slovenije 2001-2006. Ljubljana: Univerza v Ljubljani, Fakulteta za družbene vede, Center za prostorsko sociologijo.

IPSS (1998). Overview of Households Projections for Japan. Tokyo: National Institute of Population and Social Security Research.

Ishikawa, T. (2005). Japan's Housing Market Enters a Transition Period. Tokyo: Economic Research Department of Japan. http://www.nli-research.co.jp/english/economics/2005/eco050829.pdf

Makino, C. (2009). Residential Investment in Japan.

http://www.fudousan-kanteishi.or.jp/english/material_e/makino_e/makino_e.html

Mandič, S. (1995). Stanovanje in država. Ljubljana: Znanstveno in publicistično središče Ljubljana.

Mandič, S. (2006). Stanovanje in kakovost življenja. In S. Mandič (Ed.), Razvojno raziskovalni projekt stanovanjska anketa, Zaključno poročilo (pp. 7-37). Ljubljana: Univerza v Ljubljani, Fakulteta za družbene vede, Inštitut za družbene vede.

Ministry of Land, Infrastructure, Transport and Tourism (MLIT) (2009). Summary of White Paper on Land (2009). Tokyo. http://tochi.mlit.go.jp/english/

Official Statistics of Japan (2010). Yearly Average of Monthly Disbursements per Household. Tokyo. http://www.estat.go.jp/SG1/estat/GL38020103.do?_toGL38020103_\&listID=000001055111\&requestSender=estat

Pšunder, I. (2009). Demografske spremembe in trg nepremičnin. 5. Portorož: Planet GV, Slovenska nepremičninska konferenca, 5-12.

Pšunder, I., \& Ferlan, N. (2009). Subjektivno dojemanje vplivnih faktorjev pri ocenjevanju vrednosti nepremičninskih pravic. Portorož: Inštitut za nepremičnine, Zbornik referatov 20. posveta Poslovanje z nepremičninami: Država, državljani, stanovanja, 246-251.

RREEF Research (2009). Japan Quarterly 2Q 2009. Tokyo. https://www.rreef.com/cps/rde/xbcr/ai_en/RREEF_-_Japan_Quarterly_2Q_2009.pdf

Rohe, W. M., Zandth, S., \& McCarthy, G. (2001). The Social Benefits and Costs of Homeownership: A Critical Assessment 
of the Research. Cambridge, MA: Joint Center for Housing Studies of Harvard University.

Rohe, W. M., \& Basolo, V. (1997). Long-Term Effects of Homeownership on the Self-Perceptions and Social Interaction of Low-Income Persons. Environment and Behavior, 29, 793-819. http://dx.doi.org/10.1177/0013916597296004

Rohe, M. W., \& Stegman, M. (1994). The Impact of Home Ownership on the Social and Political Involvement of Low-Income People. Urban Affairs, 152-172. http://dx.doi.org/10.1177/004208169403000108

Rohe, M. W., \& Stewart, L. S. (1996). Home Ownership and Neighborhood Stability. Housing Policy Debate, 7, 7-81.

Statistični urad RS (SURS) (2009). Slovenija v številkah 2009. Ljubljana. http://www.stat.si/

Tarik, M. (1990). The Impact of the Surrounding Environment on People’s Perception of Major Urban Environmental Attributes. Architecture and Planning, 2, 43-60.

Temeljotov Salaj, A., \& Zupančič, D. (2006).Odnos do nepremičnin in organizacijskega okolja. Ljubljana: Slovenski inštitut za revizijo.

Thomas, M. (2008). Generation Y and Housing, Carpe Diem. The Australian Journal of Business and Informatics, 4, 111119.

Tomoko, K. (2010). Decision-Making Process on Residential Choice of Condominium Residents: A Case Study of the Residents in Down-Town Area of Local City, Japan. Japanese Journal of Human Geography (Jimbun-Chiri), 62, 1-29.

Trček, F. (2005). Sociološka anketna raziskava, Prenova stanovanjskih sosesk v Ljubljani-Savsko naselje. Urbani Izziv, 16, 24-35. http://dx.doi.org/10.5379/urbani-izziv-2005-16-02-003

Walonic, D. S. (2007). Survival Statistics. Bloomington, MN: StatPac, Inc..

Wong, J. T. Y., \& Hui, E. C. M. (2006). Power of Expectations. Property Management, 24, 496-506. http://dx.doi.org/10.1108/02637470610710547 
Scientific Research Publishing (SCIRP) is one of the largest Open Access journal publishers. It is currently publishing more than 200 open access, online, peer-reviewed journals covering a wide range of academic disciplines. SCIRP serves the worldwide academic communities and contributes to the progress and application of science with its publication.

Other selected journals from SCIRP are listed as below. Submit your manuscript to us via either submit@scirp.org or Online Submission Portal.
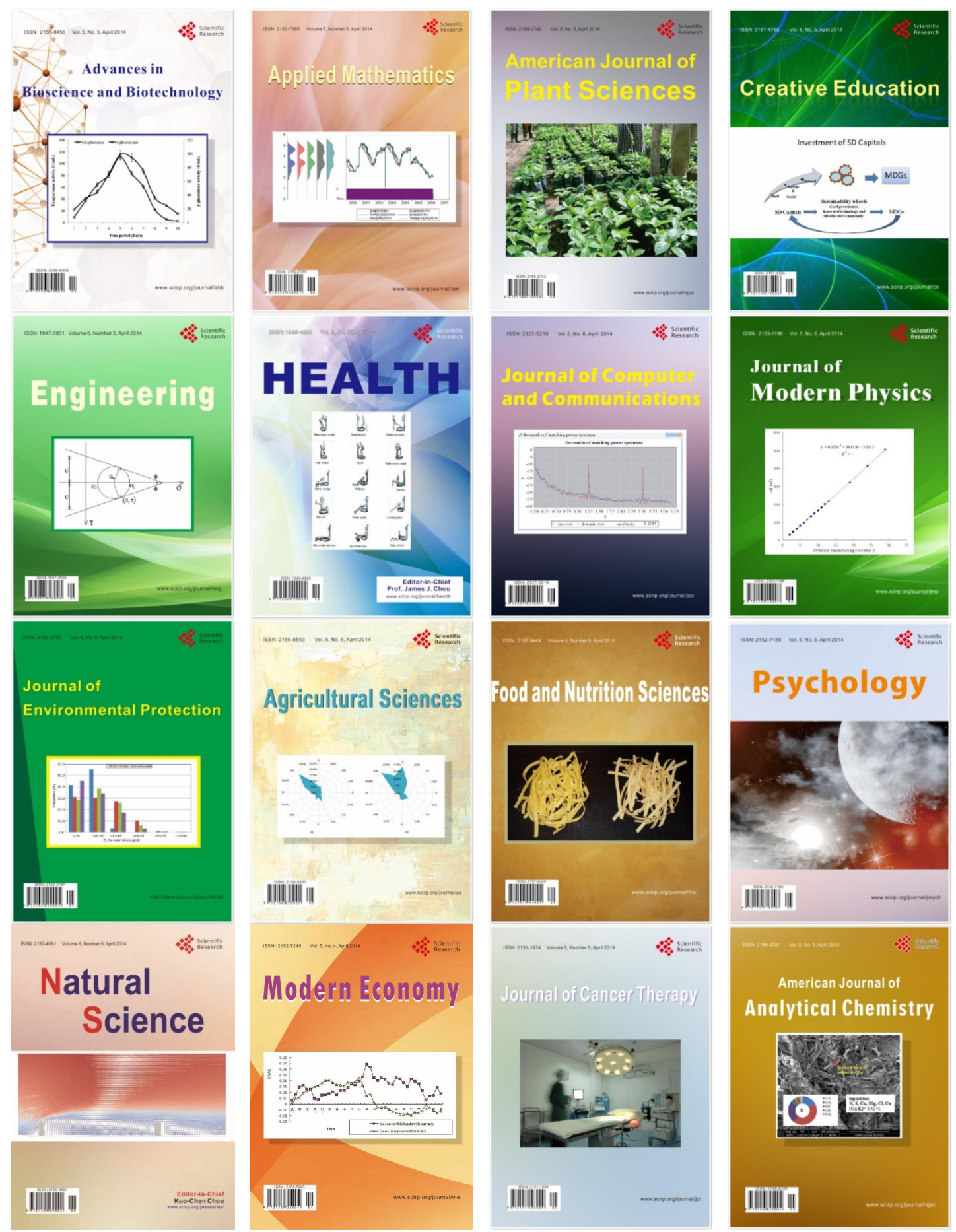